\title{
Cellular and Molecular Characterisation of the Hyper Immunoglobulin M Syndrome Associated with Congenital Rubella Infection
}

\author{
Rohan Ameratunga • See-Tarn Woon • \\ Wikke Koopmans • John French
}

Received: 29 April 2008 / Accepted: 9 June 2008 /Published online: 29 July 2008

(C) The Author(s) 2008

\begin{abstract}
Introduction The hyper-immunoglobulin $\mathrm{M}$ syndrome (HIM) is a rare group of immune deficiency disorders characterised by normal or increased serum IgM with normal or reduced $\operatorname{IgG}, \operatorname{IgA}$ and $\operatorname{IgE}$.

Materials and Methods We have undertaken detailed cellular and molecular studies in a 53-year-old man with HIM as a result of congenital rubella.

Results No mutations were detected in the CD40 ligand, activation-induced cytidine deaminase and uracil DNA glycosylase. His T-cell responses to lectins and antigens were normal. Flow cytometry confirmed the presence of CD40 ligand on activated T cells. Most CD40-dependent functions that were tested, including B-cell proliferation, isotype switching and production of memory B cells, were normal. CD40/IL4 dependent rescue from anti-IgMinduced apoptosis was impaired.

Conclusion The detection of cell-surface IgG but lack of serum IgG indicated that he may have an antibody secretion defect.
\end{abstract}

Keywords Hyper-IgM · rubella · non X-linked · isotype switching

\footnotetext{
R. Ameratunga $(\square) \cdot$ S.-T. Woon $\cdot$ W. Koopmans

Department of Virology \& Immunology, Auckland City Hospital, Auckland, New Zealand

e-mail: rohana@adhb.govt.nz

J. French

Department of Cardiology,

Liverpool Hospital and University of New South Wales,

Sydney, Australia
}

\section{Introduction}

The hyper-immunoglobulin M syndrome (HIM) is a group of immune deficiency disorders characterised by normal or elevated serum levels of IgM and normal or reduced IgG, $\operatorname{IgA}$ and $\operatorname{IgE}[1]$. Patients with the X-linked form of the disorder (XHIM) are susceptible to Pneumocystis jiroveci and Cryptosporidium parvum [2]. XHIM occurs when mutations in the CD40 ligand (CD40L) prevents B cells from undergoing immunoglobulin class switching [3]. However, some HIM patients have normal CD40L sequence and function [4, 5]. Mutations in activation-induced cytidine deaminase (AICDA), uracil DNA glycosylase (UNG) and CD40 can also lead to HIM as a result of impaired immunoglobulin class switching [6-9].

A small proportion of patients with congenital rubella develop a syndrome with recurrent infections and an immunoglobulin profile similar to that of XHIM [10-13]. With the advent of widespread immunisation, congenital rubella has become a rare disorder in developed countries. Most of these patients were described before the widespread availability of sophisticated molecular diagnostic tools.

In this report, we describe a patient with congenital rubella who developed HIM. He has normal CD40L sequence and function. No mutations were found in the AICDA and UNG genes. Several CD40 dependent B-cell functions were normal. He can generate switched memory B cells. Immunoglobulin isotype switching was observed both in vivo and in vitro. CD40/IL4 dependent rescue from anti-IgM-induced apoptosis was impaired. We postulate that the patient may have a defect in immunoglobulin secretion since cell surface $\operatorname{IgG}$ was detected despite low serum IgG. 


\section{Materials and Methods}

Patient This study was approved by the University of Auckland ethics committee. Patient M1 is a 53-year-old man born at term to non-consanguineous parents. His mother suffered a rash during pregnancy and was diagnosed as having rubella. The patient was born with impaired vision and sensorineural hearing loss. He requires a hearing aid. At the age of 3 years, he presented with recurrent upper and lower respiratory tract infections and was found to be severely hypogammaglobulinemic. In 1961, the serum gamma globulin fraction was absent. In 1984, the $\operatorname{IgG}$ was below $2.5 \mathrm{~g} / \mathrm{L}$ (normal range $8-16 \mathrm{~g} / \mathrm{L}$ ). He was commenced on intramuscular and subsequently intravenous immunoglobulin (IVIG), which led to a decrease in the number of infections. Family history revealed no relatives with recurrent infections or unexplained deaths in early childhood. The patient's sister and her son and daughter are in good health.

Apart from chronic tiredness and chronic sinusitis, he currently maintains reasonable health. Although he has a chronic cough, CT scans of the thorax failed to show any evidence of bronchiectasis. Referral to the immunology clinic at the Auckland Starship Hospital in 1992 established the presence of grossly elevated polyclonal $\operatorname{IgM}$ consistent with HIM. IgM levels of up to $15 \mathrm{~g} / \mathrm{L}$ (normal range 0.4 $2.5 \mathrm{~g} / \mathrm{L}$ ) were noted on several occasions. A graphical depiction of his immunoglobulin levels are shown in Fig. 1. High doses of IVIG ( $1 \mathrm{~g} / \mathrm{kg}$ per month) were given to the patient and another patient with XHIM, in order to reduce
Fig. 1 Immunoglobulin levels for patients XHIM and M1 from 1987 to 1993 . The increasing $\mathrm{IgG}$ levels reflect increased monthly IVIG doses. The top panel shows the immunoglobulin profile for the patient with XHIM. The bottom panel shows the immunoglobulin profile for patient M1. Note that the data from infusion 21 may have been a laboratory error. The gap at infusion 37 represents a period where data was not available. High-dose IVIG was commenced at this time. Normal ranges $\operatorname{IgG}(8-16 \mathrm{~g} / \mathrm{L}), \operatorname{IgM}$ (04-2.5 g/L), IgA (0.8-4.0 g/L)

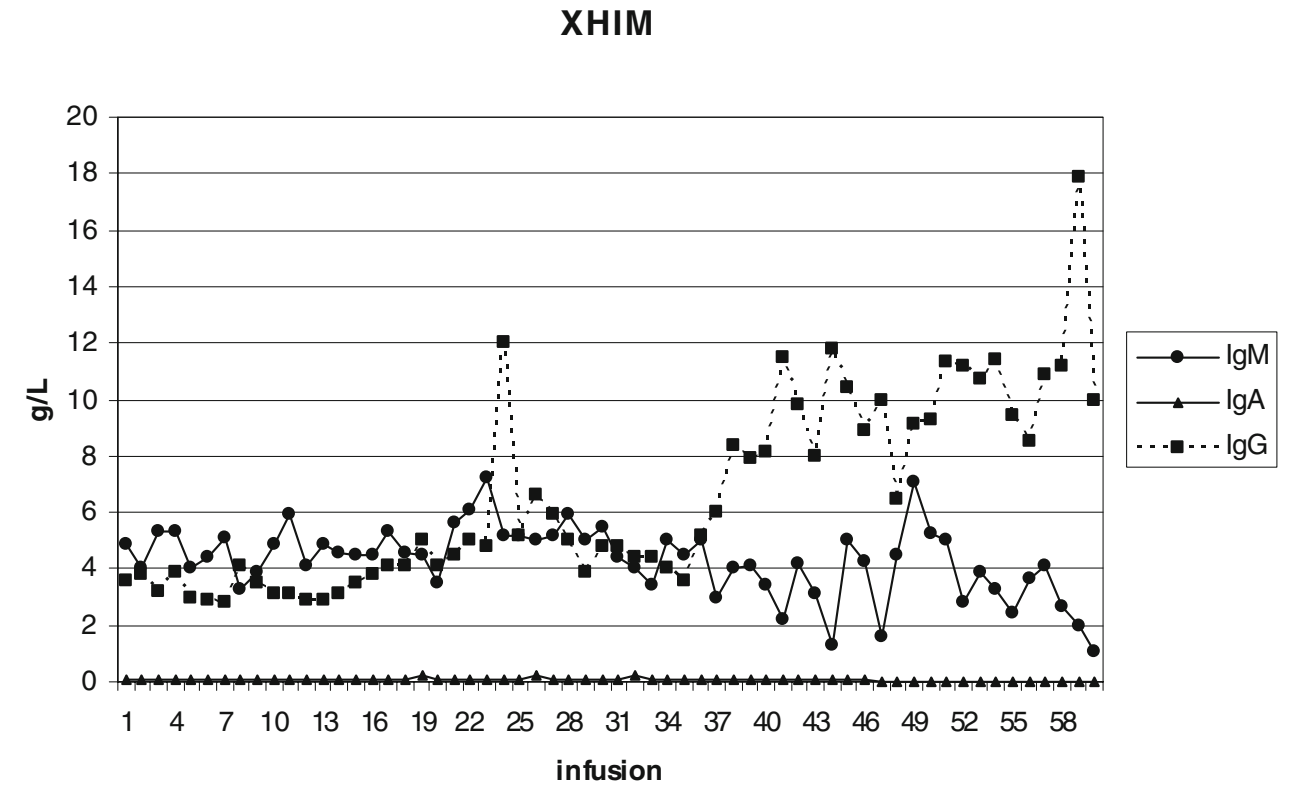

Patient M1

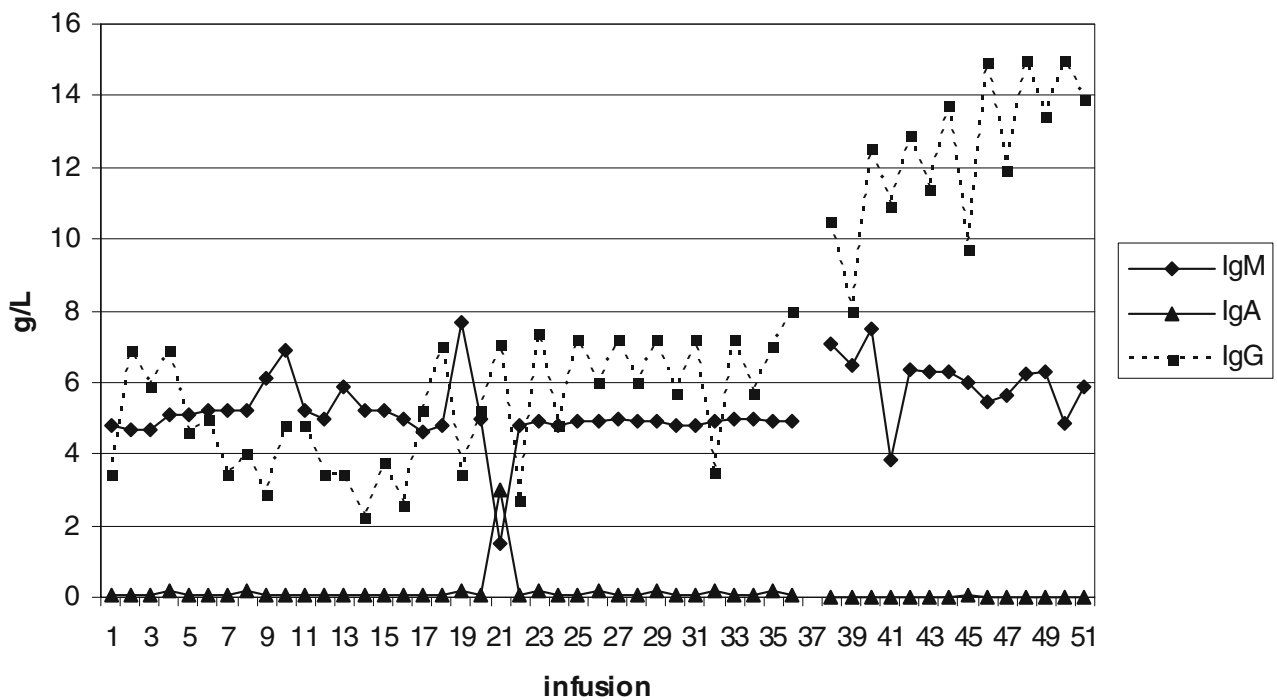


B-cell proliferation and thus minimise the risk of B-cell malignancy. A progressive reduction in IgM was noted in the patient with XHIM. In contrast, patient M1 had further increases in his IgM level. Serum and salivary $\operatorname{IgA}$ and serum IgE were undetectable. Serum and urine electrophoresis on multiple occasions excluded a monoclonal gammopathy. His absolute and percentage CD4 and CD8 T-cell numbers were within normal range.

Reagents Reagents were purchased from the following sources: tetanus toxoid (Lederle-Praxis Biologicals Inc, Pearl River, NY), diphtheria toxoid (Statens Seruminstitut, Denmark), Candida antigen (Greer Labs, Lenoire, NC), pokeweed mitogen (PWM), phytohaemagglutinin (PHA), concanavalin A (ConA) and calcium ionophore A23187 (Sigma, St. Louis, MO), anti-IgG4 (Unipath, Birmingham, UK), anti-IgM, IgG4 and biotin-conjugated anti-IgG4 antibody (Sigma Immunochemicals). Anti-CD3 monoclonal antibody (OKT3) was purchased from the Auckland Hospital Pharmacy. CD40L trimer and cytokines were gifts from Immunex Research and Development Corporation. All other antibodies were from Beckman Coulter (Fullerton, CA).

Isolation of peripheral blood mononuclear cells Peripheral blood mononuclear cells (PBMC) were isolated from a Ficoll-Hypaque gradient as previously described [14].
Fig. 2 Untreated (panel I) and $\mathrm{PMA} /$ calcium ionophore A23187 treated (panel II) T cells from patient M1 (a), patient with XHIM (b) and healthy control (c) were stained for cell surface CD40L expression
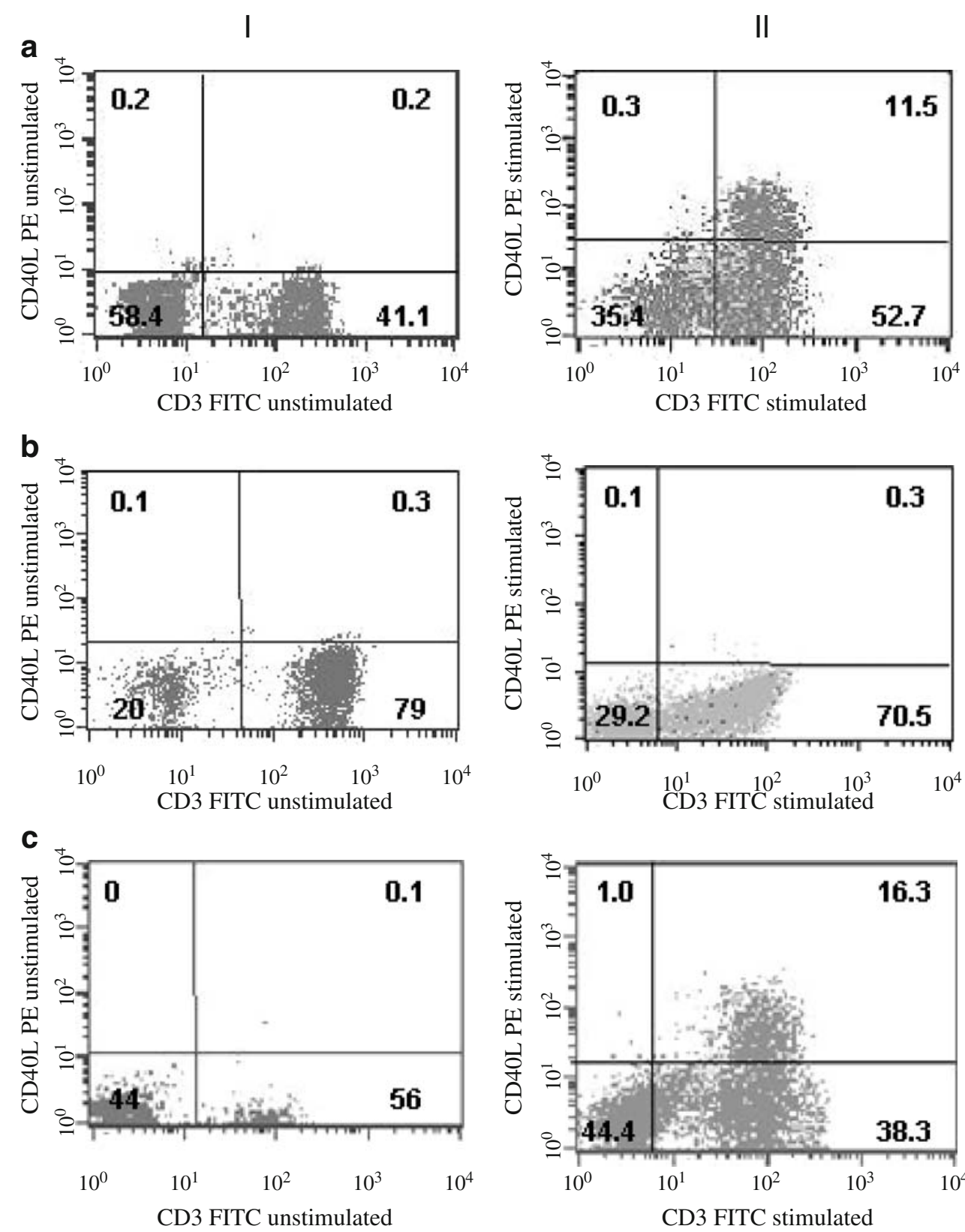
Genetic Studies Peripheral blood mononuclear cells were stimulated for $16 \mathrm{~h}$ with phorbol ester (PMA) $(500 \mathrm{ng} / \mathrm{ml})$ and PWM $(10 \mu \mathrm{g} / \mathrm{ml})$ prior to extraction of RNA. Complementary DNA was synthesised following RNA extraction. The CD40L gene was amplified in two overlapping fragments. The polymerase chain reaction (PCR) products were then ligated into the TA vector system (Promega, Madison, WI) and competent Escherichia coli cells were transformed. Colonies containing inserts were selected and subjected to bidirectional sequencing of M13 cloned products. UNG and AICDA were amplified as follows: $3 \mathrm{~min}$ at $95^{\circ} \mathrm{C} ; 40$ cycles of $30 \mathrm{~s}$ at $95^{\circ} \mathrm{C}, 30 \mathrm{~s}$ at $57^{\circ} \mathrm{C}, 50 \mathrm{~s}$ at $68^{\circ} \mathrm{C} ; 72^{\circ} \mathrm{C}, 5 \mathrm{~min}$. We aligned the three gene sequences with published wild-type sequences [8, 9, 14] using SeqManII 5.01 (DNASTAR, Madison, WI).

T-cell Proliferation Assays T-cell proliferation was determined by responses to T-cell-dependent lectins (PHA, ConA, PWM) and OKT3 as well as a panel of soluble antigens (Candida, tetanus and diphtheria) as previously described [15]. Lectins and antigens $(10 \mu \mathrm{g} / \mathrm{ml})$ were incubated in triplicate with PBMCs. T-cell proliferation was determined by the uptake of ${ }^{3} \mathrm{H}$-thymidine $(1 \mu \mathrm{Ci} /$ well $)$ for PHA, ConA and OKT3 on day 3 and PWM and the antigens on day 7. Normal controls were performed in parallel. A positive response was defined to be a stimulation index (SI, stimulated-background/background) of $>5$ for antigens and of $>10$ for lectins [16].

B-cell Proliferation Assays Purified B-cell preparations were obtained by negative selection. PBMCs were initially resuspended in RPMI $/ 10 \%$ fetal calf serum (FCS) and adhered for $2 \mathrm{~h}$ at $37^{\circ} \mathrm{C}$ in tissue culture flasks to exclude macrophages. The cells were then subjected to two rounds of sheep red blood cell rosetting to remove $\mathrm{T}$ cells. Purified B cells from patient M1, XHIM and a healthy control were incubated with IL-4 $(10 \mathrm{ng} / \mathrm{ml}), \mathrm{CD} 40 \mathrm{~L}$ trimer [17] or combination of both for 3 days. The apoptotic effect of surface $\operatorname{IgM}(\mathrm{sIgM})$ ligation was examined with a combination of anti-IgM $(10 \mu \mathrm{g} / \mathrm{ml})$ and CD40L trimer [17]. B-cell proliferation was determined by ${ }^{3} \mathrm{H}$-thymidine incorporation on day 4 as described previously [15]. The purity of B-cell preparations was assessed by absence of responses to PHA. These preparations had a SI $<2$.

In Vitro IgG4 Antibody Production Peripheral blood mononuclear cells were incubated with IL-4 $(10 \mathrm{ng} / \mathrm{ml})$ for 10 days in RPMI1640/10\% FCS. IgG4 production was determined with a sandwich enzyme-linked immunosorbent assay (ELISA) format. Unlabelled anti-IgG4 $(5 \mu \mathrm{g} /$ plate $)$ was coated onto ELISA plates. After blocking the plates with bovine serum albumin, cell supernatant was added and incubated for $1 \mathrm{~h}$ at $37^{\circ} \mathrm{C}$ prior to the addition of $1: 1,000$ biotin-conjugated anti-IgG4 antibody. Following a 1-h incubation at $37^{\circ} \mathrm{C}$, horseradish peroxidase-conjugated streptavidin was added before development with $o$-phenylene diamine. Serum and salivary immunoglobulin levels were detected by nephelometry.

Flow Cytometry Peripheral blood mononuclear cells were stimulated for $16 \mathrm{~h}$ with PMA $(500 \mathrm{ng} / \mathrm{ml})$ and calcium ionophore A23187 (50 ng/ml) prior to assessing CD40L expression on a Becton-Dickinson FACSCAN flow cytometer. Naïve, memory and switched memory B cells were phenotyped with anti-CD19-APC, antiCD27-FITC and anti-IgD-PE. Naïve and memory CD4 and CD8 $\mathrm{T}$ cells were quantified with CD45RA-FITC, CD45RO-APC and CD62L-PE antibodies. A healthy control and a patient with well-characterised XHIM [14] were used for comparison. This patient was previously shown to have a complex splicing defect of the CD40 ligand.

\section{Results}

No Pathogenic Mutations Detected in CD40L, AICDA and UNG Genes of Patient M1

The CD40L sequence of patient M1 was in complete agreement with the published wild-type sequence [18], indicating that patient M1 does not have XHIM. His AICDA and UNG gene sequences were also normal.

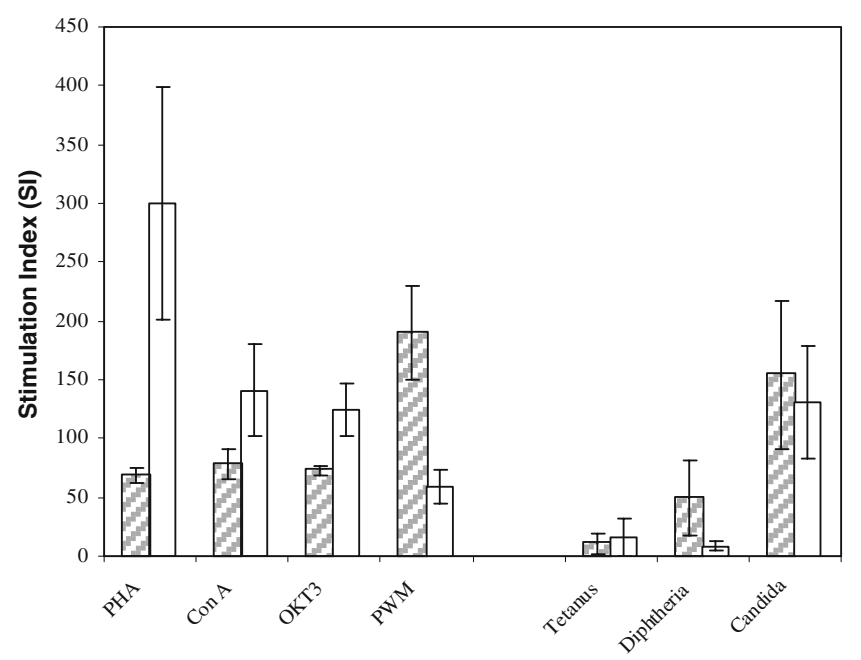

Fig. 3 In vitro T-cell proliferation in patient $\mathrm{M} 1(\square)$ and healthy control $(\square)$. PBMCs were stimulated with PHA, Con A, PWM, OKT3 $(10 \mu \mathrm{g} / \mathrm{ml})$ and Candida antigen, diptheria and tetanus toxoids $(10 \mu \mathrm{g} / \mathrm{ml})$. We have previously shown normal lectin proliferation and defective antigen responses in XHIM (15) 
Table I Memory T-cell Phenotyping

\begin{tabular}{|c|c|c|c|c|c|c|}
\hline & \multicolumn{3}{|l|}{$\mathrm{CD} 4$} & \multicolumn{3}{|l|}{ CD8 } \\
\hline & Healthy controls & XHIM & Patient M1 & Healthy controls & XHIM & Patient M1 \\
\hline Naïve $T$ & $47 \pm 14$ & 70 & 7.8 & $46.9 \pm 13$ & 33 & 18 \\
\hline Central memory & $38.7 \pm 10$ & 26 & 55 & $16.9 \pm 6$ & 41 & 18 \\
\hline Effector memory & $14.1 \pm 7$ & 8.9 & 40 & $22.4 \pm 6$ & 25 & 31 \\
\hline Terminal effector memory & $2.04 \pm 1$ & 0.3 & 5.7 & $16.1 \pm 8$ & 2.6 & 24 \\
\hline
\end{tabular}

CD4 and CD8 T cells were sorted into naïve T cells $(C D 45 R A+62 L+)$, central memory $(C D 45 R O+62 L+)$, effector memory $(C D 45 R O+62 L-)$ and terminal effector memory (CD45RA+62L-). The normal ranges for the memory T-cell subsets were obtained from 21 healthy controls.

\section{Patient M1 Showed Normal CD40L Expression on Activated T Cells}

CD40L expression in patient M1, XHIM and a healthy control were examined. Resting and activated PBMCs were stained with anti-CD3-FITC and anti-CD40L-PE to detect cell surface CD40L expression (Fig. 2). Both patient M1 and the healthy control showed normal CD40L expression on activated $\mathrm{T}$ cells (Fig. 2. IIa and IIc, upper right quadrant). CD40L-expressing $\mathrm{T}$ cells in patient M1 were $11.5 \%$, which was comparable to the $16.3 \%$ in the control sample. In contrast, the XHIM patient failed to express CD40L (Fig. $2 \mathrm{IIb}$ ).

\section{Patient M1 has Normal Proliferative Responses to Lectins and Antigens}

Patient M1 was thought to have received childhood immunisations, which included tetanus, diphtheria and polio vaccines. Patients with XHIM have defective T cell responses to soluble antigens $[19,20]$. At a time he was lymphopenic, he had impaired responses to lectins and antigens. However, more recently the lymphopenia has resolved and patient M1 had normal responses to both lectins and antigens (Fig. 3). Signalling through the TCR complex with OKT3 was slightly reduced. Similar reduced responses to PHA and ConA were observed. Response to PWM was above that of a healthy control. PBMCs proliferate appropriately in response to PMA and in combination with A23187 (data not shown).
Naïve and Memory CD4/CD8 T-cell Profiles in Patient M1

Naïve and memory CD4+ and CD8+ cell subsets in healthy controls, XHIM and patient M1 were analysed by flow cytometry (Table I). Patient M1 showed markedly decreased numbers of naïve $T$ cells, considerably below the lower percentile of the normal controls. Most of his helper $\mathrm{CD} 4+$ cells were central and effector memory cells, with a slightly higher than normal proportion of terminal effector memory $\mathrm{T}$ cells. We observed an almost normal profile in the analysed CD8 cells. The central, effector and terminal effector memory CD8 cells in patient M1 are within the normal range. Interestingly, the XHIM patient has a high percentage of naïve CD4 cells and a defect in the differentiation of terminal memory CD4 and CD8 cells.

\section{Naïve and Memory B-cell Profile in Patient MI}

The percentage of naïve (CD27-IgD+), memory (CD27+ $\operatorname{IgD}+)$, switched memory (CD27+IgD-) and immature naïve (CD27IgD-) B cells in patients M1 and XHIM were compared to the ranges obtained from 14 healthy individuals (Table II). As expected, the XHIM patient could not generate memory B cells. Switched memory B cells are almost non-existent. Patient M1 is able to generate memory and switched memory $\mathrm{B}$ cells within the ranges of healthy controls.

\section{B Cell Proliferation and Function in Patient M1}

Since CD40 expression on B cells of patient M1 was reduced ( $38 \%$ of $\mathrm{B}$ cells stained) compared to a healthy

Table II Memory B-cell Phenotyping

\begin{tabular}{lccr}
\hline & Healthy controls & XHIM & Patient M1 \\
\hline Naïve B & $69.1 \pm 14$ & 94 & 66.3 \\
Memory B & $15.5 \pm 7$ & $<5$ & 12.3 \\
Switched memory B & $12.1 \pm 7$ & $<1$ & 11.5 \\
Immature naïve B & $3.2 \pm 1$ & $<1$ & 9.9 \\
\hline
\end{tabular}

B cells were sorted into naïve B cells (CD27-IgD+), memory (CD27+IgD+), switched memory (CD27+IgD-) and immature naïve (CD27-IgD-). The normal ranges for the memory B-cell subsets were obtained from 14 healthy controls. 
Fig. 4 B-cell proliferation in patient M1 ( $\square$ ), XHIM (凅) and a healthy control (四) after their purified B cells were treated with (A) CD40L trimer and/ or IL-4 (10 ng/ml), and (B) antiIgM with IL-4 or CD40L trimer. The results were one of the two experiments in triplicates. Control is yeast supernatant. *Not determined in XHIM

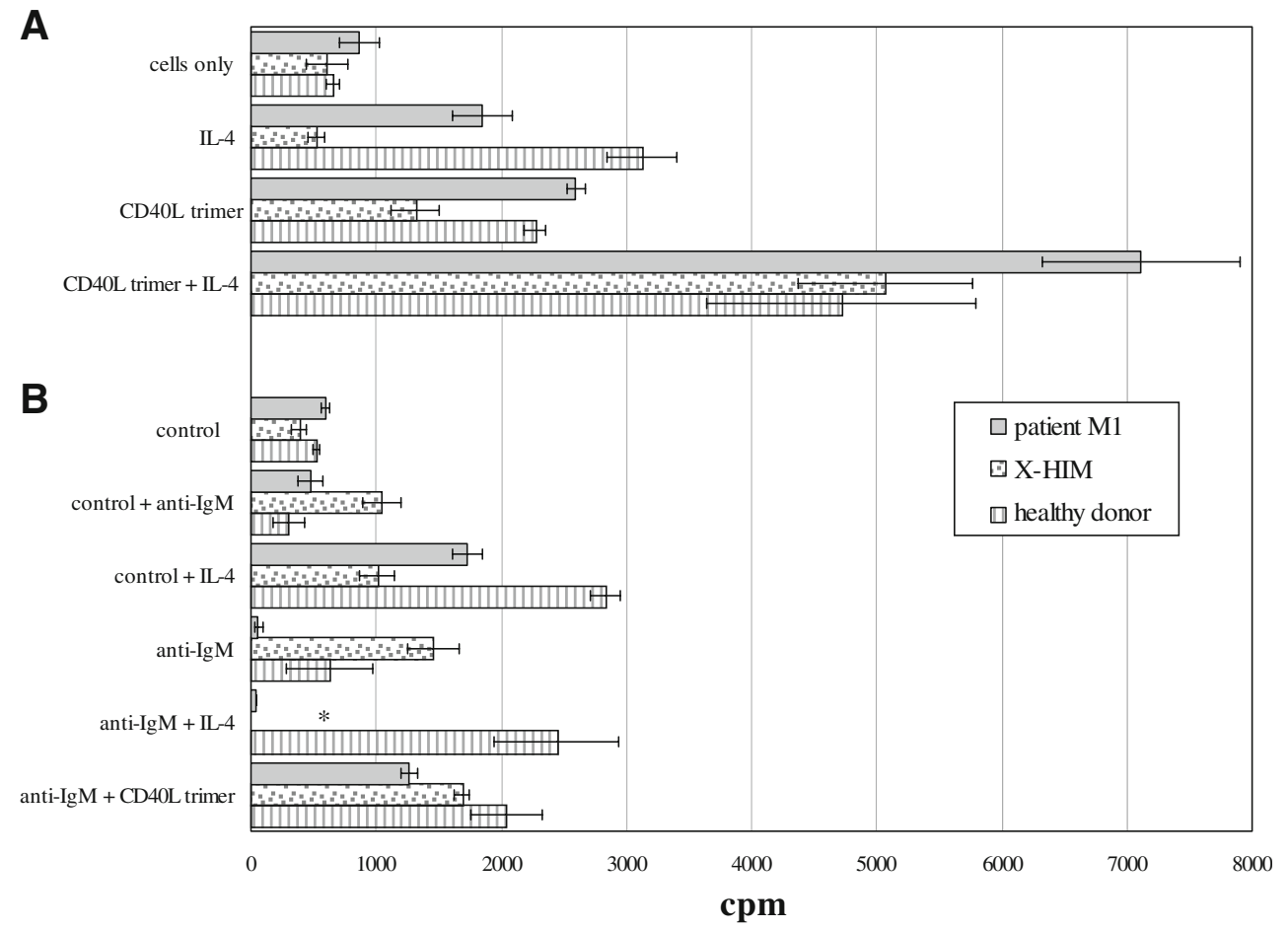

control (68\% B cells stained, data not shown), we examined CD40-dependent responses in patient M1. B-cell proliferation in response to CD40 stimulation was determined in a healthy control, patients M1 and XHIM (Fig. 4A). Purified $\mathrm{B}$ cells from patient $\mathrm{M} 1$ and the healthy control proliferate appropriately in response to IL-4, CD40L trimer and CD40L trimer/IL-4 combination (Fig. 4A). No significant increase in B-cell response was detected in XHIM treated with IL-4 alone, although responses to CD40L trimer and CD40L trimer/IL-4 combination were significant. A synergistic effect upon exposure to CD40L trimer/IL-4 combination was observed in all three individuals.

sIgM ligation delivers a potent anti-proliferative signal to the B cells of patient M1 (Fig. 4B). Ligation of sIgM resulted in ${ }^{3} \mathrm{H}$-thymidine uptake level in patient $\mathrm{M} 1$ lower than the background level. Addition of CD40L trimer, but not IL-4, could reverse the suppressive effect of sIgM ligation on the B cells from patient M1. In contrast, the anti-apoptotic effect of anti-IgM on B cells of the healthy control can be overcome with either IL-4 or CD40L trimer. A surprising observation was noted where anti-IgM increased B-cell proliferation in the XHIM patient. Coincubation of CD40L trimer with anti-IgM had no effect on the anti-IgM-induced proliferative effect on $\mathrm{B}$ cell in XHIM. These results suggested that some IL-4-dependent pathways are impaired in patient M1.

Patient M1 produced $80 \mathrm{ng} / \mathrm{ml}$ of $\mathrm{IgG} 4$ in response to IL-4 in vitro (normal range $90-240 \mathrm{ng} / \mathrm{ml}$ ). He was able to generate peripheral blood B cells bearing cell surface IgG and $\operatorname{IgA}$ in addition to cell surface IgM cells (Table III). In contrast, the XHIM patient produces sIgM, but not sIgG and $\operatorname{sig}$ A positive B cells.

\section{Discussion}

Patient M1 presented us with a unique opportunity to study in detail the pathogenesis of the hyper-IgM syndrome associated with congenital rubella. In the past 30 years, rubella vaccination has all but eliminated the disease from developed countries. Several early reports identified a disorder with a similar but milder phenotype compared to XHIM [21]. Some reports suggested improvement of the immune defect over time [22], which could account for our patient's clinically benign course.

Although the precise molecular defect in patient M1 remains elusive, our observations indicate that the biology of the disorder is fundamentally different from that of XHIM and the other B-cell switching defects described

Table III Immunophenotyping Profiles of XHIM and Patient M1

\begin{tabular}{lccc}
\hline$\%$ surface marker & Normal range & XHIM & Patient M1 \\
\hline SIgG & $1-5$ & 0 & 5 \\
SIgA & $1-5$ & 0 & 2 \\
SIgM & $1-5$ & 5 & 4 \\
\hline
\end{tabular}

The normal range for established assays is based on the mean \pm 2 standard deviations for a normal population. The units are the percentage of cells stained with the labelled monoclonal antibody. 
recently [23]. In contrast to patients with XHIM, patient M1 had no history of neutropenia or hemolytic anemia. He was consistently and profoundly lymphopenic for several years, a feature typically not associated with XHIM. The unexplained lymphopenia subsequently resolved. His CD40L, UNG and AICDA gene sequences were normal, thus ruling out mutations in the known genes responsible for X-linked and autosomal HIM.

Unlike XHIM patients who have defective T-cell responses to soluble antigens but normal lectin responses [15], patient M1 responded to soluble antigens and lectins, albeit at reduced level. The OKT3 response was only slightly reduced (Fig. 3). The normal response to PMA/ A23187-induced CD40L expression is also consistent with functional T cells (Fig. 2). Patient M1 is able to generate terminal memory T-cells (Table I), which strengthens the argument for normal T-cell function. However, a specific defect T-cell cytokine production cannot be excluded by these studies. The low naïve CD4 cells identified in patient M1 mirrors those of the two female HIM patients reported by Costa-Carvalho et al. [24] Whether the low naïve CD4 cells are a characteristic feature of other non X-linked HIM disorders requires further investigation.

Patient M1 suffered mostly bacterial infections of the upper and lower respiratory tracts, reminiscent of defective B-cell function. This clinical picture contradicts his seemingly normal in vitro B-cell proliferation profile (Fig. 4A). His switched memory $\mathrm{B}$ cells were within the normal range (Table II). He is able to produce $\operatorname{sg} \mathrm{A}+$ and $\operatorname{sIgG}+$ bearing peripheral blood B cells (Table III) and detectable amounts of IgG4 in vitro. These results indicated that immunoglobulin isotype switching was possible in vivo and in vitro, consistent with normal CD40L function. In contrast, no switched memory B cells and no $\operatorname{sgG}+$ and $\operatorname{sig} A+B$ cells were identified in the patient with XHIM (Tables II and III). Given the presence of cell surface IgA and IgG but nondetectable serum IgA and IgG, we postulate that patient M1 has an Ig secretory defect.

Both patients were treated with high-dose IVIG in order to suppress B-cell proliferation (Fig. 1). This may reduce the risk of B-cell lymphomas in HIM. The patient with XHIM showed a reduction in IgM level with increasing dose of IVIG, suggesting reduced B-cell activation, proliferation and secretion. This feedback inhibition was not seen in patient M1. This is further in vivo evidence that the two defects are fundamentally different.

We observed abnormal CD40/IL4 function in patient M1. Ligation of SIgM has a profound apoptotic effect on immature B cells [25]. Ligation of sIgM resulted in marked suppression of B-cell proliferation in patient M1, an effect that could be reversed by addition of CD40L trimer but not IL-4 (Fig. 4B). The mechanism for the increased sensitivity of $\mathrm{B}$ cells to sIgM ligation was not determined but may indicate the presence of immature B cells. However, the suboptimal signalling through the CD40 pathway could be due to reduced cell-surface CD40 expression. If the B-cell defect in patient M1 was due to abnormal cell surface CD40 expression, considerable redundancy of the CD40 pathway may explain some apparently normal CD40dependent functions such as B-cell proliferation in response to the CD40L trimer. Perhaps the rescue from the sIgMinduced anti-proliferative effect is critically dependent on the expression of normal levels of CD40.

Palacin et al. [10] described an 18-year-old girl with hyper-IgM and autoimmune disorder in association with rubella. The patient has normal T-cell proliferation (P.S. Palacin, personal communication) and can generate memory B cells [10], both of which are consistent with what we observed in patient M1. More importantly, our results suggest that the hyper-IgM syndrome phenotype may be broader than previously thought.

Our data have shown that the hyper-IgM syndrome phenotype can be produced even when the immunoglobulin isotype switching mechanism is intact. Whether patients with a B-cell maturation defect should be considered as part of the spectrum of hyper-IgM disorders will be the subject of future research.

Acknowledgments This work was supported by Ruth Spencer Medical Research Fellowship (to R.A.) and the Immune Deficiency Foundation of New Zealand (IDFNZ). We thank the patient for his enthusiasm in wanting this report published for the benefit of others. R.A. wishes to thank Dr. Kitty Croxson and Gayl Humphrey for their support. We thank Dr. William Fanslow of Immunex Corporation (Seattle, WA) for the recombinant CD40L trimer. We thank Danny Lim, Olivia Ng and Michelle Petrasich for undertaking flow cytometry studies.

Open Access This article is distributed under the terms of the Creative Commons Attribution Noncommercial License which permits any noncommercial use, distribution, and reproduction in any medium, provided the original author(s) and source are credited. WK was a student at the University of Groningen during this work.

\section{References}

1. Etzioni A, Ochs H. The hyper IgM syndrome-an evolving story. Pediatr Res. 2004;56:519-25. doi:10.1203/01.PDR.0000139318.65842.4A.

2. Winkelstein JA, Marino MC, Ochs H, Fuleihan R, Scholl PR, Geha R, et al. The X-linked hyper-IgM syndrome: clinical and immunologic features of 79 patients. Medicine (Baltimore). 2003;82:373-84. doi:10.1097/01.md.0000100046.06009.b0.

3. Notarangelo LD, Lanzi G, Peron S, Durandy A. Defects of classswitch recombination. J Allergy Clin Immunol. 2006;117:855-64. doi:10.1016/j.jaci.2006.01.043.

4. Durandy A, Hivroz C, Mazerolles F, Schiff C, Bernard F, Jouanguy E, et al. Abnormal CD40-mediated activation pathway in B lymphocytes from patients with hyper-IgM syndrome and normal CD40 ligand expression. J Immunol. 1997;158:2576-84.

5. Oliva A, Quinti I, Scala E, Fanales-Belasio E, Rainaldi L, Pierdominici M, et al. Immunodeficiency with hyperimmunoglo- 
bulinemia $\mathrm{M}$ in two female patients is not associated with abnormalities of CD40 or CD40 ligand expression. J Allergy Clin Immunol. 1995;96:403-10. doi:10.1016/S0091-6749(95) 70060-9.

6. Rada C, Williams GT, Nilsen H, Barnes DE, Lindahl T, Neuberger MS. Immunoglobulin isotype switching is inhibited and somatic hypermutation perturbed in UNG-deficient mice. Curr Biol. 2002;12:1748-55. doi:10.1016/S0960-9822(02)01215-0.

7. Ferrari S, Giliani S, Insalaco A, Al-Ghonaium A, Soresina AR, Loubser M, et al. Mutations of CD40 gene cause an autosomal recessive form of immunodeficiency with hyper $\operatorname{IgM}$. Proc Natl Acad Sci USA. 2001;98:12614-9. doi:10.1073/pnas.221 456898.

8. Revy P, Muto T, Levy Y, Geissmann F, Plebani A, Sanal O, et al. Activation-induced cytidine deaminase (AID) deficiency causes the autosomal recessive form of the Hyper-IgM syndrome (HIGM2). Cell 2000;102:565-75. doi:10.1016/S0092-8674(00)00079-9.

9. Imai K, Slupphaug G, Lee WI, Revy P, Nonoyama S, Catalan N, et al. Human uracil-DNA glycosylase deficiency associated with profoundly impaired immunoglobulin class-switch recombination. Nat Immunol. 2003;4:1023-8. doi:10.1038/ni974.

10. Palacin PS, Castilla Y, Garzón P, Figueras C, Castellví J, Español T. Congenital rubella syndrome, hyper-IgM syndrome and autoimmunity in an 18-year-old girl. J Paediatr Child Health. 2007;43:716-8. doi:10.1111/j.1440-1754.2007.01144.x.

11. Marshall WC, Weston HJ, Bodian M. Pneumocystis carinii pneumonia and congenital hypogammaglobulinaemia. Arch Dis Child. 1964;39:18-25.

12. Hong R, Schubert WK, Perrin EV, West CD. Antibody deficiency syndrome associated with beta-2 macroglobulinemia. J Pediatr. 1962;61:831-42. doi:10.1016/S0022-3476(62)80193-0.

13. Goddard EA, Hughes EJ, Beatty DW. Hyper IgM with combined immunodeficiency. J Clin Lab Immunol. 1991;35:183-8.

14. Ameratunga R, McKee J, French J, Prestidge R, Fanslow W, Marbrook J. Molecular pathology of the X-linked hyper-immunoglobulin $\mathrm{M}$ syndrome: detection of wild-type transcripts in a patient with a complex splicing defect of the CD40 ligand. Clin Diagn Lab Immunol. 1996;3:722-6.

15. Ameratunga R, Lederman HM, Sullivan KE, Ochs HD, Seyama $\mathrm{K}$, French JK, et al. Defective antigen-induced lymphocyte proliferation in the X-linked hyper-IgM syndrome. J Pediatr. 1997;131:147-50. doi:10.1016/S0022-3476(97)70139-2.

16. Valentine F, Lederman H: LPA Protocols version 2.0 (aactg.s-3. $\mathrm{com} / \mathrm{pub} /$ download/imm /imlpaadu.pdf) Feb 2000

17. Fanslow W, Srinivasan S, Paxton R, Gibson M, Spriggs M, Armitage R. Structural characteristics of CD40 ligand that determine biological function. Semin Immunol. 1994;6:267-78. doi:10.1006/smim.1994.1035.

18. Graf D, Korthauer U, Mages HW, Senger G, Kroczek RA. Cloning of TRAP, a ligand for CD40 on human T cells. Eur J Immunol. 1992;22:3191-4. doi:10.1002/eji.1830221226.

19. Subauste CS, Wessendarp M, Sorensen RU, Leiva LE. CD40 CD40 ligand interaction is central to cell-mediated immunity against Toxoplasma gondii: patients with hyper IgM syndrome have a defective type 1 immune response that can be restored by soluble CD40 ligand trimer. J Immunol. 1999;162:6690-700.

20. Garcia-Perez MA, Paz-Artal E, Corell A, Moreno A, LopezGoyanes A, Garcia-Martin F, et al. Mutations of CD40 ligand in two patients with hyper-IgM syndrome. Immunobiology 2003;207:285-94. doi:10.1078/0171-2985-00241.

21. Benkerrou M, Gougeon ML, Griscelli C, Fischer A. Hypogammaglobulinemia $\mathrm{G}$ and $\mathrm{A}$ with hypergammaglobulinemia $\mathrm{M}$. Apropos of 12 cases. Arch Fr Pediatr. 1990;47:345-9.

22. Kawamura N, Okamura A, Furuta H, Katow S, Yamada M, Kobayashi I, et al. Improved dysgammaglobulinaemia in congenital rubella syndrome after immunoglobulin therapy: correlation with CD154 expression. Eur J Pediatr. 2000;159:764-6. doi:10.1007/PL00008342.

23. Durandy A, Taubenheim N, Peron S, Fischer A. Pathophysiology of B-cell intrinsic immunoglobulin class switch recombination deficiencies. Adv Immunol. 2007;94:275-306. doi:10.1016/ S0065-2776(06)94009-7.

24. Costa-Carvalho B, Viana M, Brunialti M, Kallas E, Salomao R. An imbalance of naive and memory/effector subsets and altered expression of CD38 on T lymphocytes in two girls with hyperIgM syndrome. Clin Exp Immunol. 2004;136:291-6. doi:10.1111/ j.1365-2249.2004.02446.x.

25. Norvell A, Mandik L, Monroe J. Engagement of the antigenreceptor of immature murine $\mathrm{B}$ lymphocytes results in death by apoptosis. J Immunol. 1995;154:4404-13. 